\title{
Diversity and bioactivities of fungal endophytes from Distylium chinense, a rare waterlogging tolerant plant endemic to the Three Gorges Reservoir
}

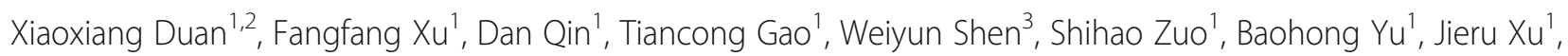
Yajun Peng ${ }^{1}$ and Jinyan Dong ${ }^{1 *}$

\begin{abstract}
Background: The present study involves diversity and biological activities of the endophytic fungal community from Distylium chinense, a rare waterlogging tolerant plant endemic to the Three Gorges Reservoir. This study has been conducted hypothesizing that the microbial communities in the TGR area would contribute to the host plant tolerating a range of abiotic stress such as summer flooding, infertility, drought, salinity and soil erosion etc., and they may produce new metabolites, which may possess plentiful bioactive property, especially antioxidant activity. Therefore in the current study, the antioxidant, antimicrobial and anticancer activities of 154 endophytes recovered from D. chinense have been investigated. Furthermore, the active metabolites of the most broad-spectrum bioactive strain have also been studied.
\end{abstract}

Results: A total of 154 fungal endophytes were isolated from roots and stems. They were categorized into 30 morphotypes based on cultural characteristics and were affiliated with 27 different taxa. Among these, the most abundant fungal orders included Diaporthales (34.4\%) and Botryosphaeriales (30.5\%), which were predominantly represented by the species Phomopsis sp. (24.7\%) and Neofusicoccum parvum (23.4\%). Fermentation extracts were evaluated, screening for antioxidant, antimicrobial and anticancer activities. Among the 154 isolates tested, 99 (64.3\%) displayed significant antioxidant activity, 153 (99.4\%) exhibited inclusive antimicrobial activity against at least one tested microorganism and 27 (17.5\%) showed exclusive anticancer activity against one or more cancer cell lines. Specifically, the crude extract of Irpex lacteus DR10-1 exhibited note-worthy bioactivities. Further chemical investigation on DR10-1 strain resulted in the isolation and identification of two known bioactive metabolites, indole-3-carboxylic acid (1) and indole-3-carboxaldehyde (2), indicating their potential roles in plant growth promotion and human medicinal value.

Conclusion: These results indicated that diverse endophytic fungal population inhabits D. chinense. One of the fungal isolate DR10-1 (Irpex lacteus) exhibited significant antioxidant, antimicrobial and anticancer potential. Further, its active secondary metabolites 1 and 2 also showed antioxidant, antimicrobial and anticancer potential.

Keywords: Distylium chinense, Bioactivity, Endophytic fungi, Identification, Metabolites

\footnotetext{
* Correspondence: donjyaa@swu.edu.cn

${ }^{1}$ Chongqing Key Laboratory of Plant Resource Conservation and Germplasm Innovation, School of Life Sciences, Southwest University, Chongqing 400715, People's Republic of China

Full list of author information is available at the end of the article
}

(c) The Author(s). 2019 Open Access This article is distributed under the terms of the Creative Commons Attribution 4.0 International License (http://creativecommons.org/licenses/by/4.0/), which permits unrestricted use, distribution, and reproduction in any medium, provided you give appropriate credit to the original author(s) and the source, provide a link to the Creative Commons license, and indicate if changes were made. The Creative Commons Public Domain Dedication waiver (http://creativecommons.org/publicdomain/zero/1.0/) applies to the data made available in this article, unless otherwise stated. 


\section{Background}

Endophytic fungi in plants are microorganisms that parasitize symbiotically in the internal tissues during the whole or part of their life cycles of the hosts without causing apparent pathogenic symptoms [1], but may turn pathogenic during host senescence [2]. Accumulated evidence has confirmed that plant endophytes from special or extreme environment has many effects on host ecological adaptability [3-5]. It is well known that the concurrence of endophytes may accelerate plant growth and increase the survival rate of biotic or abiotic stresses, such as plant diseases, pests, drought, salinity and extreme temperatures [6-9]. Specifically, some endophytes are beneficial to plants by producing special substances, such as secondary metabolites, which can prevent the host from being attacked successfully by fungi and pests [10]. So far, endophytes, especially those under complex and extreme conditions, have been shown to produce a variety of metabolites with complex structures, such as alkaloids, terpenoids, polyketides, lipids, glycosides, isoprenoids, and hybrids of those metabolites, etc. [11-13]. More interestingly, these metabolites also showed a variety of interesting bioactivities including antifungal [14], antibacterial [15], anticancer [16], anti-HIV [17], antioxidants [18], etc. Due to these, endophytes from an untapped diverse habitat are a significant source of novel and natural drugs [19].

After Three Gorges Dam is constructed, the Three Gorges Reservoir (TGR) forms a new vast hydrofluctuation belt with an elevation of $145 \mathrm{~m}$ in summer to $175 \mathrm{~m}$ in winter, a length of more than $2000 \mathrm{~km}$ and an area of $300 \mathrm{~km}^{2}[20,21]$, which has provided unique ecological habitats for those diverse species in the TGR area [22]. Many field surveys have shown that most of the pre-dam riparian vegetation is gradually dying out due to the inability to adapt to the reversal of submergence time, the prolongation of flood duration and the new hydrological fluctuation zone (up to $30 \mathrm{~m}$ in elevation) [23]. Generally, plants use limited oxygen and light under flood conditions, resulting in production of excessive reactive oxygen species (ROS) [24], which were the key factors that hindered the growth and development of submerged plants $[25,26]$. They are forced to undergo the oxidative pathway [27], and usually develop an antioxidant defense system consisting of some antioxidant enzymes and specific metabolites to convert these excessive ROS into harmless products in order to protect themselves [28, 29].

As symbionts, endophytic fungi can produce antioxidants, block the chain reaction of ROS to help host plants respond to various biotic and abiotic stresses [9, 30]. Some studies have also showed that endophytes can increase the survival rate of host plants during flooding stress by producing antioxidants independently [31, 32].
Severe oxidative damage of free radicals has been confirmed to be associated with various diseases, including cancer, inflammation, aging and neurodegenerative diseases [33]. It has been advised that antioxidants should be warranted in the enhancement of human health [34, 35]. Currently, the demand for natural antioxidants from endophytic fungi has been increasing along with the finding that natural antioxidants have fewer side effects on human health than artificially synthesized substances $[36,37]$. Additionally, the search for safer and novel drugs based on the natural product from endophytes is of utmost importance because of the increasing incidence of cancer and the recently emerged, rapid evolution of superbugs due to antibiotic resistance [38, 39].

After Three Gorges Dam is constructed, many abiotic stresses in the natural habitat strongly influence plant growth and development, such as summer flooding, infertility, drought, salinity and soil erosion etc. So far, only a few highly tolerant plants have been reported to survive, which include Salix variegate, Morus alba L., Myricaria laxiflora [22, 40]. Among them, Distylium chinense (Fr.) Diels, a rare evergreen ornamental shrub of Hamamelidaceae family known for the beautiful flowers (Fig. 1a), is a native species to the riparian wetland in the TGR area of the Yangtze River and its tributaries [20, 41, 42]. Since 2005, D. chinense was considered as an ideal choice for solid embankment after the construction of the Three Gorges Dam owing to its strong root system, erosion tolerance, strong flooding tolerance and resistance to sand burial soaks [43]. Several biological studies have been made for $D$. chinense such as morphological characteristics, natural habitat, genetic diversity, community structure, ecological adaptability, reproductive allocation and propagation methods [42, 44, 45]. It should be noted that the roots of $D$. chinense has been used in traditional Chinese medicine and folk medicine as an analgesic, antirheumatic and diuretic [46]. However, there is no information on the diversity and bioactive potential of endophytes community from $D$. chinense. Thus, the aim of this study was to provide the first evidence of endophytic fungi diversity within the $D$. chinense, provide a working collection of endophytes and investigate endophytes with antioxidant, antimicrobial and anticancer activities in order to explore the potential sources of novel drugs.

\section{Methods}

\section{Plant material}

Three healthy and asymptomatic $D$. chinense plants were randomly collected from different locations on an island in the Banan district (N2942'45.63", E10660'69.43") of Chongqing of China in the Three Gorges Reservoir area in October 2014. All plant materials were immediately sent to the laboratory and stored in a refrigerator at $4^{\circ} \mathrm{C}$. 


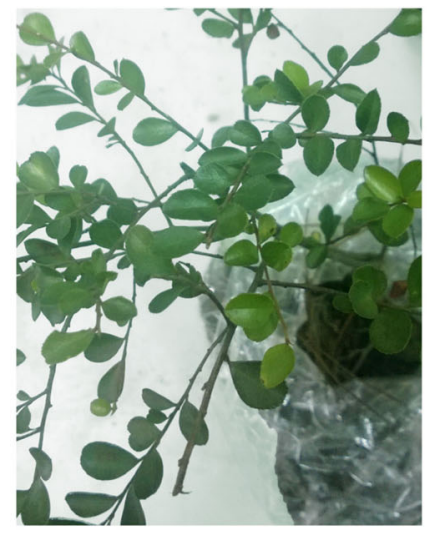

A

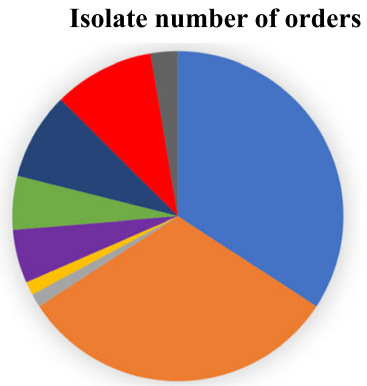

C

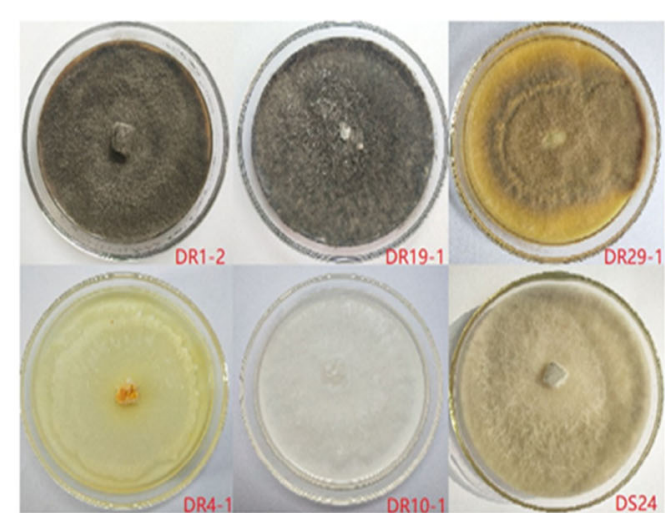

B
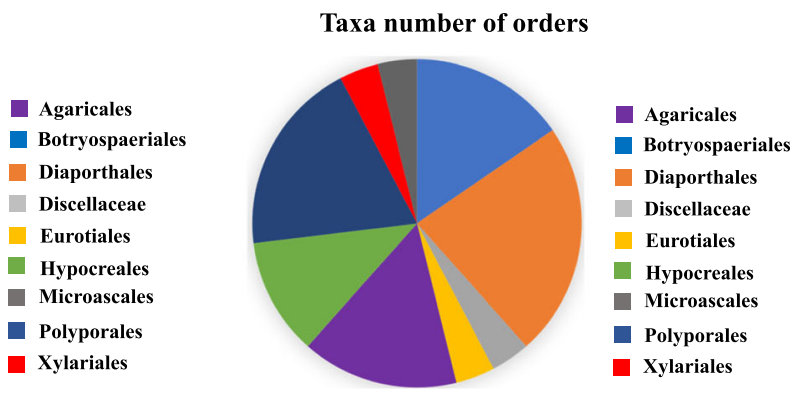

D

Fig. 1 D. chinense plant and taxonomic distribution of endophytic fungi. (a) D. chinense plant. (b) Representative fungal morphotypes isolated from D. chinense growing on potato dextrose agar (PDA) for one week at $26^{\circ} \mathrm{C}$. (c) Distribution of fungal isolates $(n=154)$ belonging to each $\operatorname{order}(n=9)$. (d) Distribution of fungal taxa $(n=27)$ belonging to each order $(n=9)$

Each sample tissues were used within $24 \mathrm{~h}$ after collection. The plant samples were identified as $D$. chinense by Prof. Hongping Deng and were preserved in Chongqing Key Laboratory of Plant Resource Conservation and Germplasm Innovation, School of Life Science, Southwest University, Chongqing 400715, China.

\section{Isolation and cultivation of endophytic fungi}

The surface sterilization and isolation of fungal endophytes were carried out, and some improvements were made [47]. In the first instance, all stems and roots of plant materials were thoroughly washed in running tap water to remove debris and then air-dried naturally in the clean bench. Clean tissue pieces were disinfected in series of solutions: $75 \%$ ethanol; sterile distilled water; $0.1 \%$ mercuric chloride $(\mathrm{HgCl})(\mathrm{v} / \mathrm{v})$. Finally, they were again rinsed with sterile distilled water three times. After surface sterilization, the tissues were dried on blotting sheets, cut into $0.5 \mathrm{~cm}$ lengths and transferred to potato dextrose agar (PDA) medium supplemented with $60 \mathrm{mg} /$ $\mathrm{mL}$ of streptomycin and $100 \mathrm{mg} / \mathrm{mL}$ of ampicillin using an aseptic technique to inhibit the bacterial growth. At the same time, the final sterile water used for washing the tissues $(100 \mu \mathrm{L})$ was also plated on the PDA to confirm the sterilization effect of the surface. The inoculated plates were incubated at $28^{\circ} \mathrm{C}$ in darkness for 2-15 days to allow the growth of endophytic fungal hyphae and checked regularly. Pure isolates were checked for purity and transferred to another PDA plate by the hyphal tip method [48]. The obtained endophytic fungal isolates were coded according to their source tissues (DR1-1, DR1-2, DR2-1, etc. from roots and DS2-1, DS31 , DS1-2, etc. from the stems). These endophytes were classified according to colony color, form, elevation and margin characteristics on PDA. Based on the groupings, strains with different morphology were screened for molecular identification.

\section{Molecular identification and phylogenetic evaluation of endophytic fungi}

According to the above simple classification, each type of fungi was chosen as the representative for molecular biological identification using the fungal genomic deoxyribonucleic acid (DNA) extraction. Fungal genomic DNA extraction was previously described by Landum et al. according to the manufacturer's instructions using the DNeasy Plant Minikit (Qiagen, Germany) [49]. The nuclear ribosomal DNA internal transcribed spacer 
(ITS) of the fungal isolates were amplified by forward primer, ITS1-F (5'-TCCGTAGGTGAACCTGCGG-3') and reverse primer, ITS4 (5'-TCCTCCGCTTATTG ATATGC-3') [50]. The final reaction volume was $25 \mu \mathrm{L}$, containing $12.5 \mu \mathrm{L}$ of $2 \mathrm{X}$ PCRBIO Taq Mix Red (PCR Biosystems, UK), $0.4 \mu \mathrm{M}$ of forward and reverse primers and $10 \mathrm{ng}$ of genomic DNA template. For negative control, the DNA was replaced with distilled water to verify absence of contamination. PCR was carried out using MyCycler ${ }^{\mathrm{TM}}$ (Bio-Rad, USA), programmed for $5 \mathrm{~min}$ $94^{\circ} \mathrm{C}$; 30 cycles for $30 \mathrm{~s}$ at $94^{\circ} \mathrm{C}, 60 \mathrm{~s}$ at $55^{\circ} \mathrm{C}$, and $1 \mathrm{~min}$ at $72^{\circ} \mathrm{C}$; and a final $10 \mathrm{~min}$ extension at $72{ }^{\circ} \mathrm{C}$. The PCR products were separated using $1 \%$ agarose gel in $1 \mathrm{X}$ TAE buffer (90mM Tris-acetate and $2 \mathrm{nM}$ EDTA, $\mathrm{pH}$ 8.0), with ethidium bromide $(0.5 \mu \mathrm{g} / \mathrm{mL})$ staining and recorded with FluorChemTM (Alpha Innotech, USA). The PCR products were sequenced by Invitrogen Co. Shanghai.

In phylogenetic evaluation, the ITS DNA sequences and downloaded sequences of their nearest neighbors were aligned in Alignment Explorer of MEGA 4 software using ClustalW option [51, 52]. MUSCLE (UPGMA) algorithm was used to prune and verify the sequence. The evolutionary distances and history were calculated by using the neighbor-Joining methods [53]. The robustness of the trees were assessed by bootstrap analysis with 1000 replication [54].

\section{Bioactivity evaluation \\ Fermentation and preparation of fungal extract}

Fermentation and preparation of the fungi were determined according to the scheme proposed by $\mathrm{Ya}-\mathrm{Li}$ et al. with some modifications [55]. Briefly, all isolates were cultured in potato dextrose broth $\mathrm{PDB}$, the medium contained potato $200 \mathrm{~g}$ and glucose $20 \mathrm{~g}$ in $1 \mathrm{~L}$ of purified water) for $14 \mathrm{~d}$ at $28{ }^{\circ} \mathrm{C}$ on a shaker at $180 \mathrm{r} / \mathrm{min}$. Crude fermentation broth was filtered with eight layers of gauze. Filtered liquid was extracted three times with the same amount of ethyl acetate. The organic solvent extract was then evaporated under reduced pressure to yield an ethyl acetate extract. The ethyl acetate extracts were dissolved in methanol and the final concentration was $10 \mathrm{mg} / \mathrm{mL}$ for bioactivity screening.

\section{Antioxidant activity}

The radical scavenging ability was evaluated by using adapted 2,2'-diphenyl-b-picrylhydrazyl (DPPH) method described previously with some modification [56]. Thus, an aliquot of extract $(50 \mu \mathrm{L})$ was added to $150 \mu \mathrm{L}$ of methanol DPPH $(50 \mu \mathrm{M})$. The reaction mixture was transferred to a 96-well microtitre plate and incubated at room temperature for $30 \mathrm{~min}$ in the dark and absorbance was measured at $517 \mathrm{~nm}$ using a microtiter plate reader (Bio-Rad 680, BIO-RAD, USA). Ascorbic acid $(\mathrm{Vc})$ and methanol were used as positive and negative controls, respectively. Meanwhile, three experimental replicates were taken for the assay.

\section{Antimicrobial activity}

The determination of antimicrobial activity was based on the disk diffusion method with some modification [57]. Each disc (Oxford cup, $6 \mathrm{~mm}$ diameter) contained $200 \mu \mathrm{g}$ of endophytic fungi extraction $(10 \mathrm{mg} / \mathrm{mL})$. The indicator organisms included gram-negative: Escherichia coli (ATCC25922, EC), Pseudomonas aeruginosa (CMCC(B)10104, PA); gram-positive: Staphylococcus aureus (ATCC6538, SA), Bacillus subtilis (ATCC6633, BS); three pathogenic fungi Penicillium (ATCC9080, P), Aspergillus niger (CMCC(F)98003, AN) and Candida albicans (CMCC(F)98001, CA). There were purchased from Shanghai Luwei Technology Co., Ltd. Streptomycin and amphotericin B were used as positive controls and methanol as negative control. The antimicrobial activities were determined according to diameters of inhibitory zones (ZI) and experiments were repeated three times.

\section{Anticancer activity}

Human papillary thyroid carcinoma cell line IHH4 and human pancreatic adenocarcinoma cell line CFPAC-1 were obtained from the Cell Line Bank of the Chinese Academy of Science. The anticancer activity was determined according to CCK-8 assay [58]. Cisplatin was used as the positive control and repeated for three times.

\section{Isolation of bioactive metabolites}

Based on the results of the above antioxidant, antimicrobial and anticancer activities, the strain Irpex lacteus DR10-1 was selected for the chemical analysis because it exhibited widest broad-spectrum bioactivities. Irpex lacteus DR10-1 culture filtrate 14L was fermented by the same method as above mentioned. Crude ethyl acetate (EtOAc) extracts from Irpex lacteus DR10-1 (6.7g) was obtained and further purified by a silica gel column (200300 mesh, $4.0 \times 70 \mathrm{~cm}$, with $70 \mathrm{~g}$ of silica gel), and eluted with gradient mixtures of petroleum ether $\left(60-90{ }^{\circ} \mathrm{C}\right)$ and EtOAc to yield 5 fractions (A1-A5). Fraction A2 (156 mg) was further purified by a silica gel column chromatography (300-400 mesh, $2.0 \times 25 \mathrm{~cm}$, with $15 \mathrm{~g}$ of silica gel) and eluted with gradient mixtures of chloroform $\left(\mathrm{CHCl}_{3}\right)$ and EtOAc to yield compound $\mathbf{1}$ (30mg). Fraction A4 (98 $\mathrm{mg}$ ) was further purified by a silica gel column chromatography (300-400 mesh, $1.0 \times 25 \mathrm{~cm}$, with $35 \mathrm{~g}$ of silica gel), and eluted with gradient mixtures of $\mathrm{CHCl}_{3}$ and methanol $(\mathrm{MeOH})$ to obtain compound $2(25 \mathrm{mg})$.

Nuclear magnetic resonance (NMR) spectra were recorded by Bruker Ascend 500 spectrometer. The spectrometer operated at $500 \mathrm{MHz}$ for ${ }^{1} \mathrm{H}$ nuclei and 125 $\mathrm{MHz}$ for ${ }^{13} \mathrm{C}$ nuclei. Chemical shift was quoted in parts 
per million (ppm), referring to the appropriate residual solvent peak.

\section{Statistical Analysis}

Using species as the statistical unit, the number of isolates $(N)$ and the isolation frequency $(I F)$ for each endophytic fungal species in different tissues or the total plant (Additional file 1 Table S1) were calculated. Species richness index $(S)$ and Margalef index $\left(D^{\prime}\right)$ were used to evaluate species richness, which were two important parameters for alpha diversity analysis [59]. Shannon-Wiener index $\left(H^{\prime}\right)$ and Simpson's diversity index $(D \mathrm{~s})$ were used to the species diversity, respectively $[60,61]$. Additionally, the Jaccard Similarity Index (JC) was used to compare the species composition of the stem and root tissues [62]. Results were expressed as mean \pm standard deviation (SD) of triplicate of measurements for the DPPH and CCK-8 assays. Data were conducted with SPSS 18.0 for Windows (SPSS Inc., Chicago, USA).

\section{Results}

\section{Community composition and abundance}

A total of 154 fungal endophytes were isolated from $D$. chinense plants collected from the TGR area. Among them, 30 different representative morphospecies were determined according to cultural characteristics (Fig. 1b). Of these detected, 30 isolates were categorized into 27 different taxa (Ascomycota, 19; Basidiomycota, 8), and further into nine distinct orders (Fig. 1c). The Fig. 2 showed the phylogenetic tree of 30 fungal strains isolated from the NCBI database and the accession numbers of the matched rDNA-ITS sequences. The supplementary table data (Additional file 1: Table S1) provided detailed information on 30 representative strains, including their sources and isolation frequencies.

At the order level, the Diaporthales possessed the most taxa, six taxa, accounting for $22.2 \%$ of the total fungal taxa and they had 48 isolates, around $31.2 \%$ of the total fungal isolates (Fig. 1d). Conversely, the Botryospaeriales had the most isolates, 52 isolates, accounting for $33.8 \%$ of the total fungal isolates and they possessed four species, around $14.8 \%$ of the total fungal species. The Polyporales and Agaricales were the second and third most abundant orders with high species, and together constituted approximately $33.3 \%$ of all the species. Analogously, the Xylariales and Polyporales were the second and third most abundant isolates, and together constituted approximately $18.1 \%$ of all the isolates. The other identified orders were the Hypocreales, Microascales, Eurotiales and Discellaceae, which together constituted approximately $22.2 \%$ and $10.4 \%$ of all species and isolates, respectively (Fig. 1d). Interestingly, the most common fungal species between roots and stems were
Phomopsis sp. (24.7\%), followed by Neofusicoccum parvum (23.4\%). However, Phomopsis were not from order with highest isolate rates.

\section{Species diversity and richness abundance of fungi}

The richness and species diversity of culturable endophytic fungi were significantly higher in stems than in roots (Table 1). Among the 27 total taxa, 16 (59.3\% of total) were obtained from the stems. A total of 3 fungal taxa- Neofusicoccum parvum, Phomopsis sp. and Diaporthe sp. were distributed in both plant tissues, but ten taxa-Fusarium sp., Fusarium equiseti, Xylaria venosula, Lasiodiplodia theobromae, Penicillium ochrochloron, Rhizoctonnia bataticola, Robillarda sessilis, Coprinellus xanthothrix, Polyporus crassa and Irpex lacteus were only found in the roots (Fig. 3). Similarly, of the nine orders, two were found in both stems and roots, but the Hypocreales, Xylariales, Eurotiales and Discellaceae were unique to the roots (Fig. 4). Additionally, ShannonWiener index $\left(H^{\prime}\right)$ and Simpson diversity index $(D s)$ could be used to analyze species diversity. Generally, the higher the Shannon's diversity index (usually between 1.5 and 4.5), the closer the Simpson's diversity index is to 1 , the stronger the adaptability of the community to the change of micro environment is, and the community presents the trend of expanding the distribution range and entering the new environment [63]. On the other hand, the species richness $(S)$ and Margalef index $\left(D^{\prime}\right)$ can reflect the richness of endophytic fungi species. The larger the values of $S$ and $D^{\prime}$ were, the richer the species of endophytic fungi were [64]. As shown in Table 1, the species richness and diversity of endophytic fungi in stems were higher than those in roots, and the values of $S$ (16), $D^{\prime}$ (3.5802), $H^{\prime}$ (2.5323) and $D$ s (0.8659) were higher. In addition, the similarity index (Jaccard's index) was used to estimate the similarity between stem and root. Although stem and root samples collected in TRG field were adjacent to each other and lived in the same place, the Jaccard's index only showed 0.11 between stems and roots, showing low similarity. These indices showed that endophytic fungi in different tissues had significant diversity.

\section{Bioactivity evaluation of fungal endophytes}

As mentioned above, one of the main purposes of this study was to identify endophytic fungi that could be cultured and applied to develop their potentially beneficial properties for plants and humans. All 154 fungal endophytes isolated from $D$. chinense at TGR were evaluated for their antioxidant, antimicrobial and anticancer activities (Additional file 1: Table S2-S4). Among the 154 isolates, 99 (64.3\%), 153 (99.4\%) and 27 (17.5\%) fungal extracts showed antioxidant activity, antimicrobial activity against at least one indicator organisms and 


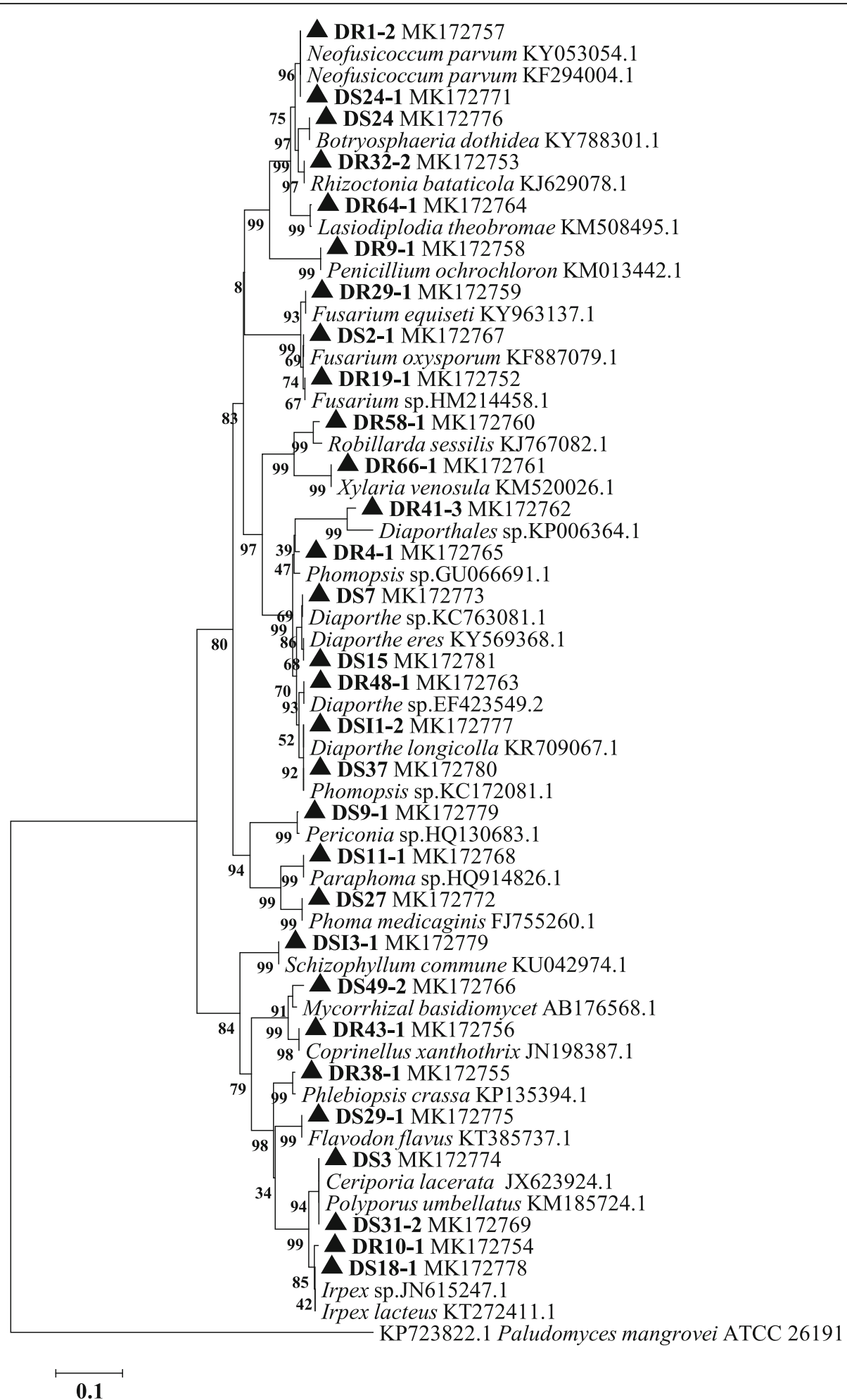

Fig. 2 Phylogeny analyses of endophytic fungi from D. chinense. The tree was derived by neighbor-joining methods analysis of ITS1-5.8S-ITS4 sequences [53] and 30 sequences retrieved from Gen Bank. The percentage of replicate trees in which associated taxa were clustered together in the bootstrap test (1000 replicates, values below 50\% are not shown) are shown next to the branches. Phylogeny analyses were conducted in MEGA 4 software $[51,52]$ 
Table 1 Diversity analyses of endophytic fungi from $D$. chinense

\begin{tabular}{llll}
\hline Diversity Index & \multicolumn{2}{l}{ Different Tissues } & Total \\
\cline { 2 - 3 } & Root & Stem & \\
\hline Species richness $(S)$ & 14 & 16 & 27 \\
Margalef index $\left(D^{\prime}\right)$ & 2.9109 & 3.5802 & 5.1619 \\
Shannon-Wiener index $\left(H^{\prime}\right)$ & 2.1828 & 2.5323 & 2.4824 \\
Simpson diversity index $(D s)$ & 0.8366 & 0.8659 & 0.8646 \\
Jaccard's indice $(J C)$ & & 0.11 & \\
\hline
\end{tabular}

anticancer activity against one or two human cancer cell lines, respectively. Among the isolates that displayed the individual activities, Phomopsis sp. accounted for 20, 38 and 4 of isolates possessing antioxidant, antimicrobial and anticancer activities, respectively (Fig. 5). Neofusicoccum parvum and Xylaria venosula were also enriched in isolates showing bioactivities. However, in our assay, the isolates belonging to Mycorrhiza basidiomycete, did not display antioxidant and anticancer activities (Fig. 5). Thus, the distribution of active strains showed obvious taxonomic specificity. Interestingly, the fungal extracts of DS16-1 (Phomopsis sp.), DR10-1 (Irpex lacteus), DS91 (Periconia sp.) and DS6 (Phomopsis sp.) showed higher antioxidant activity than that of ascorbic acid, acted as a scavenger of DPPH radical with $\mathrm{IC}_{50}$ values of $2.59 \pm$ $0.03,2.79 \pm 0.04,2.95 \pm 0.03$ and $2.97 \pm 0.01 \mu \mathrm{g} / \mathrm{mL}$, respectively. For the antimicrobial activity, fungal extract of DR28-1 (Phomopsis sp.) displayed the highest antimicrobial activity against Pseudomonas aeruginosa with a zone of inhibition (ZI) value of $40 \mathrm{~mm}$, fungal extract of DS35-1 (Ceriporia lacerta) showed the highest antimicrobial activity against Staphylococcus aureus, with a ZI value of $40 \mathrm{~mm}$, the fungal extracts of DR41-2
(Ceriporia lacerta) had the highest activity against Aspergillus niger, and its ZI value was $30 \mathrm{~mm}$. Particularly, the extract DR10-1 (Irpex lacteus) was the only strain that exhibited broad antimicrobial capability because it inhibited the growth of all tested pathogens. As for anticancer activity, fungal extract of DR46-1 (Phomopsis sp.) showed the highest anticancer activity against $\mathrm{IHH} 4$ cell line with $\mathrm{IC}_{50}$ values of $9.20 \pm 0.02 \mu \mathrm{g} / \mathrm{mL}$.

\section{Characterization of metabolites of strain DR10-1}

Among 154 strains recovered from $D$. chinense, the EtOAc extract of the culture broth of Irpex lacteus DR101 (Additional file 2: Figure S1-S2) exhibited higher antioxidant activity than that of ascorbic acid, antimicrobial capability by inhibiting the growth of seven tested pathogens and showed anticancer activity against both tested cancer cell lines, and was subjected to column chromatography over silica gel, Seqhadex LH-20 to afford two known compounds. The structures of the two known compounds were established as indole-3-carboxylic acid (compound 1) [65] (Additional file 2: Figure S3-S4) and indole-3-carboxaldehyde (compound 2) [66] (Additional file 2: Figure S5-S6) by comparing their spectroscopic data with those in the literature (Fig. 6)

\section{Discussion}

Considering the roles of endophytic fungi in plant development, growth, adaptability and diversity, we needed to fill this gap in order to exploit of endophytes for a better understanding of $D$. chinense plant and their important metabolites found in the TGR. Therefore, one of the purposes of this study was to examine the community composition of fungal endophytes from TGR. Here, we

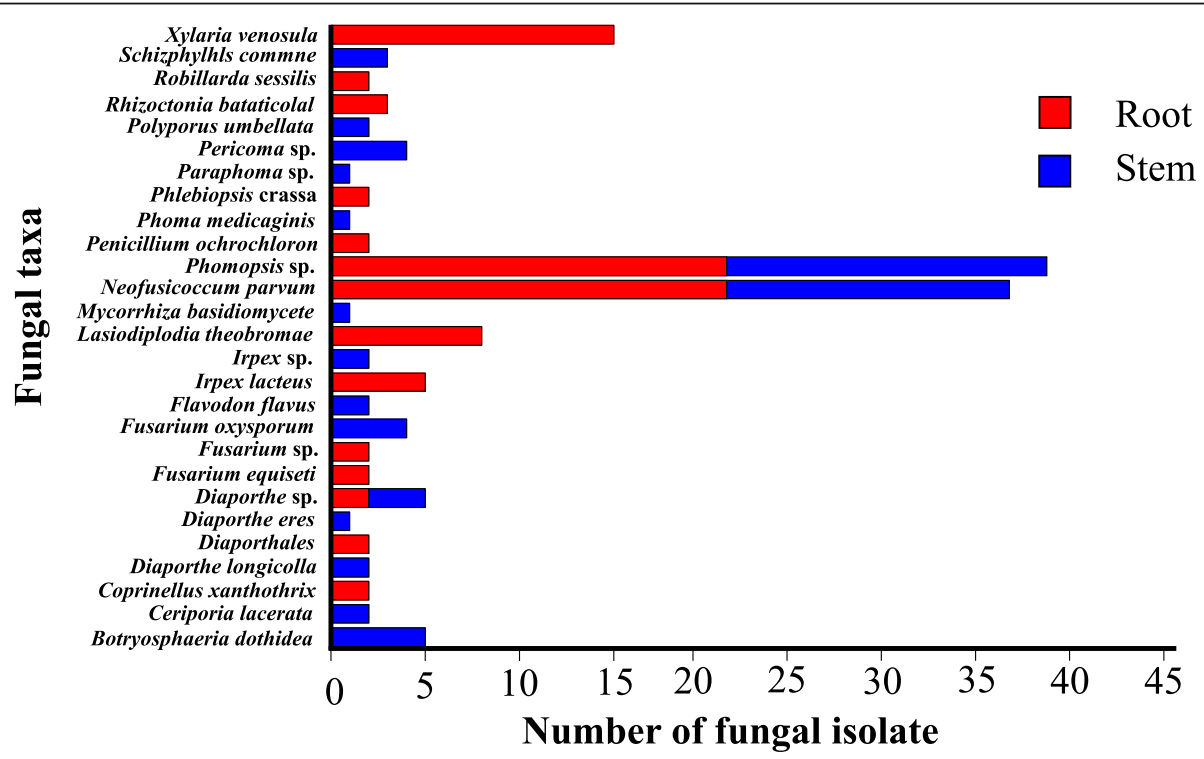

Fig. 3 Distribution of the fungal isolates $(n=154)$ across different plant tissues 


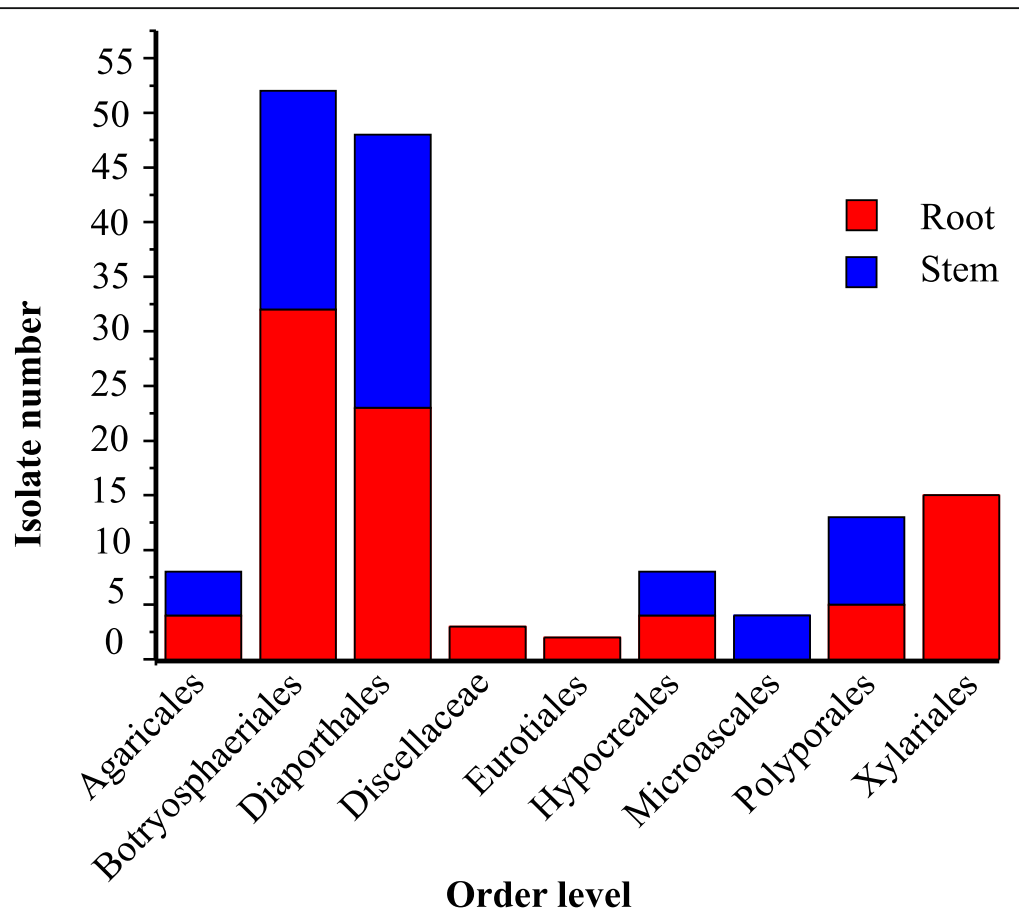

Fig. 4 Distribution of the orders of the fungal isolates $(n=154)$ from different tissues

took a culture-dependent approach, since our final goal was to build a working collection of fungal endophytes that could be explored for their potentially beneficial properties in $D$. chinense plant. In this work, a total of 154 endophytic fungi were isolated from D. chinense in the TGR and classified into 27 different taxa according to their morphological characteristics and unique phenotypic characters. The identified fungi were mainly composed of Phomopsis, N. parvum, Diaporthe, Fusarium and Irpex with relative frequencies $24.7 \%, 23.4 \%, 3.2 \%$, $5.2 \%$ and $4.5 \%$, respectively. Among them, fungi that belong to Phomopsis, Diaporthe, Fusarium and Irpex have

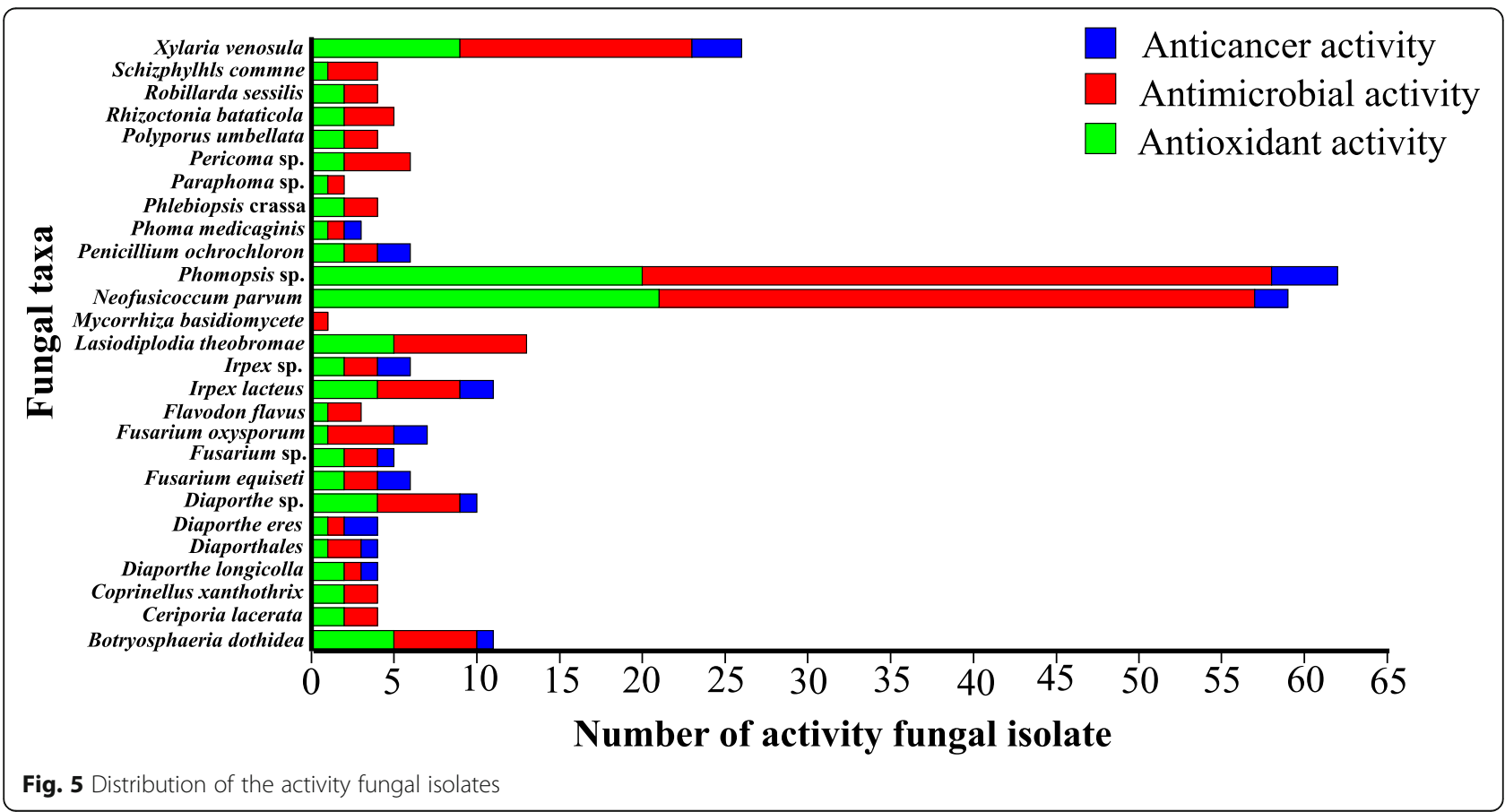




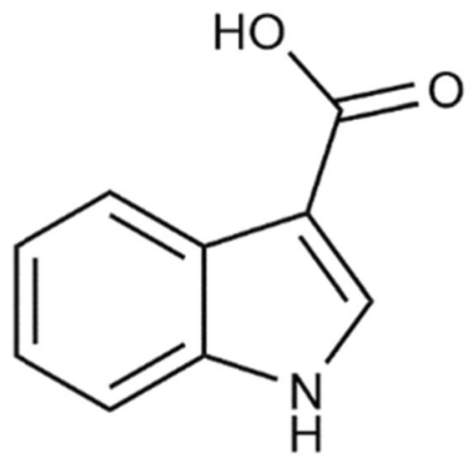

1

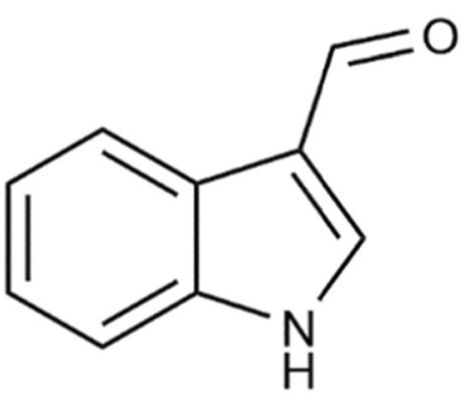

2

Fig. $\mathbf{6}$ The chemical structure of compounds $\mathbf{1 - 2}$

been reported as the main endophytes of wetland shrub Myricaria laxiflora in the TGR [67] and riparian plant species [68]. Additionally, Fusarium, Phomopsis and Irpex has also been reported to be not sensitive to flooding stress [67]. By contrast, other several genera, including Penicillium ochrochloron, Mycorrhizal basidiomycete, Ceriporia lacerta, Diaporthe longicolla, Diaporthe eres, Flavodon flavus, Irpex sp., Parphoma sp. and Phoma medicaginis, were only isolated from D. chienense with low relative abundance. Even so, the existence of these minor genera has been demonstrated to play an important ecological role in their host plants as reported [69].

According to the literatures, fungal endophytic community of land plant mainly belonged to Sordariomycetes, Dothideomycetes and Pezizomycetes fungi while plants from water or moist environments were more often parasitized by Eurotiomycetes [70-72]. In the current study, the most prevalent class was Sordariomycetes with relative frequency of $50 \%$, followed by Dothideomycetes and Eurotiomycetes at $33.8 \%$ and $1.3 \%$, respectively. Obviously, both terrestrial and aquatic fungi are present in the $D$. chinense plant. This was in accordance with the report by Kandalepas et al., who discovered high numbers of Sordariomycetes and low numbers of Dothideomycetes and Eurotiomycetes in wetland plants from Louisiana [71].

It has been reported that dark septate endophytes (DSE) could be important as (latent) saprobes, playing a role in host nutrition through complex substrate degradation, and might help to degrade organic matter in nutrient-poor soils in a similar way as ericoid mycorrhizal fungi-mutualistic symbionts that benefit the host plant by mobilizing complex substrates in nutrient poor environments [73]. Here, 7 taxa out of 27 taxa detected were found to be darkly pigmented with thickly walled septate hyphae that can be classified into dark septate fungi, which include Diaporthales, Phomopsis sp., Lasiodiplodia theobromae, Neofusicoccum parvum, Irpex lacteus, Periconia sp., Botryosphaeria dothidea [74]. According to our statistics, 20 (13.0\%) from 154 isolates belong to this group. In our previous paper, Salix variegata, another waterlogging tolerant plant in the TGR area, has also been found to be colonized by abundant DSEs [75]. This was in accordance with the report on the occurrence of DSEs in wetland plant species $[76,77]$.

Among these isolates found in $D$. chinense, many from the genera Phomopsis, Fusarium, Diaporthe, Neofusicoccum parvum, Xylaria venosula, Lasiodiplodia theobromae and Botryosphaeria dothidea have been reported as common pathogenic fungi in some wild and cultured plants [75]. For examples, Diaporthe and Phomopsis complex were the causes of seed decay and cause soybean blight and canker diseases [78]; Neofusicoccum parvum was reported as one of the most aggressive causal agents of the trunk disease Botryosphaeria dieback [79]; Botryosphaeria and its anamorph complex were particularly important for symptoms such as fruit rot, shoot blight, dieback and canker of numerous woody hosts [80]. Although the symptoms of disease did not appear in $D$. chinense plant collected, as reported, these fungi might switch their lifestyles from a mutualistic to parasitic interaction which depended on genetic factors of both partners [81], imbalance in nutrient exchange [82] and environmental variations [83, 84]. Furthermore, the interaction type between an endophyte and a host plant also could be modulated if the plant was subjected to physiological stress [85]. It has been shown that individual fungal species which could switch lifestyles might represent an evolutionary transition, or simply fungi that had achieved remarkable ecological plasticity, might ensure the optimal growth and reproduction in a variety of hosts, which ultimately would lead to the expansion of 
their bio-geographic distribution [81]. As a whole, mutualistic interactions between fungal invaders and host plants are deciphered as a balance, which is considered as a combination of environmental and physiological effects that benefit both sides [82]. Fitness benefits conferred by mutualistic fungi contribute to or are responsible for plant adaptation to biotic and abiotic stress [86, 87].

Another objective of this study was to assess the potentially beneficial properties of endophytic fungi to humans. All the endophytes extracts were screened for antioxidant, antimicrobial and anticancer activities and they showed at least one biological activity. Among the screened isolates, 99 (64.3\%) isolates exhibited remarkable antioxidant activity, of which 18 $(11.7 \%)$ had very notable activity with $\mathrm{IC}_{50}$ value of $\leq$ $3 \mu \mathrm{g} / \mathrm{mL}$, suggesting that it may protect $\mathrm{D}$. chinense from oxidative stress in the flooding environment as suggested by Zeng et al [88]. Because of the protective effect of antioxidants, they are essential for plant survival and fitness and presumably selection have leaded to both redundant and highly specific pathways that address ROS production and stress mediation [89]. For example, Mirzahosseini et al. have reported that endophytic fungi can alleviate the oxidative damage produced by ROS accumulation in plant cells such as $F$. arundinacea $[90,91]$. Regarding antimicrobial activity, $31.2 \%, 11.7 \%, 19.5 \%, 69.5 \%$ and $29.9 \%$ extracts of endophytes showed activity against Penicillium, Candida albicans, Aspergillus niger, Staphylococcus aureus and Escherichia coli respectively, which was comparable and even exceeded some results reported by other authors in similar studies [92, 93]. For example, from the 39 endophytic fungal extracts of Viguiera arenaria and Tithonia Diversifolia plants, Guimaraes et al. found only $5.1 \%$ and $25.6 \%$ extracts to be active against Staphylococcus aureus and Escherichia coli respectively [94]. Unexpectedly, Pseudomonas aeruginosa was most sensitive to the fungal extracts among the tested bacterial though it was reported to be drug resistant towards many antibiotics [95]. Usually, the fungal extracts also showed higher activity against the Gram-negative than the Gram-positive ones. This different sensitivity has been suggested to be attributed to the high level of lipopolysaccharides that are contained in the Grampositive bacteria membrane, which could make the cell wall impermeable to bioactive compounds [96]. As for anticancer activity, 27 out of 154 fungal exacts (17.5\%) showed activity against IHH4/CFPAC-1 cell line, in which 11 fungal extracts were active against both tested cell lines. Statistically, 18 out of 27 anticancer isolates were exclusively isolated from the roots, 9 were only recovered from stems. Generally, for the same fungal species e.g. Neofusicoccum parvum, the isolates from roots showed stronger bioactivity compared to those from the stems regardless of antimicrobial, antioxidant or anticancer bioactivities. Such data well supported the traditional practice of native people who often used the extracts from roots to relieve analgesic, antirheumatic and diuretic [43].

Of these isolates screened, a high proportion of bioactivities were mostly detected from the fungal extracts belonging to Phomopsis sp. (24.7\%), Neofusicoccum parvum (23.4\%) and Xylaria venosula (9.1\%), which was attributed to their high separation rate. As did here, Phomopsis sp. have been reported as dominant member of the endophytic community [97]. Phomopsis is a dominant member of the endophytic community because it grows rapidly, thus inhibiting slow growing endophytes, which might be one of the reasons for the low number of species detected in this study [98]. Additionally, Phomopsis and related taxa contain important endophytic and are known to produce a series of bioactive secondary metabolites in vitro with a variety of different chemical structures [99]. However, few studies conducted on the active metabolites of Neofusicoccum parvum, and its antioxidant activity accounted for the highest proportion in the current study, which has never been reported in previous studies [100, 101]. Besides, Xylaria species are widely distributed on the temperate to the tropical zones in the terrestrial globe, and fungi of this genus have been proved to be potential sources of novel secondary metabolites, and many of them have biological activities related to drug discovery, including cytotoxic, antimalarial, and antimicrobial activities [102]. In terms of bioactivity, active extracts of DS16-1 (Phomopsis sp.), DR28-1 (Phomopsis sp.), DS35-1 (Ceriporia lacerata), DR41-2 (Ceriporia lacerata) and R46-1 (Phomopsis sp.) were found promising. In particular, the strain DR10-1(Irpex lacteus) showed wide spectrum bioactivities, suggesting that possible use of one endophyte could be a valuable candidate as new antioxidant, antimicrobial and anticancer agents.

Finally, we isolated two known compounds including indole-3-carboxylic acid and indole-3-carboxylic acid derivatives from the wide spectrum bioactive strain I. lacteus DR10-1. As far as we know, this was the first time that indole-3-carboxylic acid (1) and indole-3carboxaldehyde (2) had been isolated from endophytic fungus Irpex lacteus. It was previously demonstrated that indole-3-carboxylic acid isolated from endophytic fungal strain of Epicoccum nigrum associated with Entada abyssinica had remarkable activity against Gramnegative strains (Staphylococcus aureus) with MIC values of $6.25 \mu \mathrm{g} / \mathrm{mL}$ [103]. This finding was consistent with literature report on the antibacterial activity of indole-3-carboxylic acid, from which a novel series of 
indole-3-carboxylic acid derivatives were previously reported to possess potent antibacterial activity against $E n$ terococcus faecalis [104]. In addition, it has been reported that indole-3-carboxylic acid had weak cytotoxic effects on both normal and tumor cells, and its antioxidant activity is weak [103]. Recently, the indole-3carboxylic acid (IAA) and other auxins have been shown to stimulate cell elongation, resulting in root growth initiation or an enhancement of nutritional elements absorption by the hosts $[105,106]$. Besides, IAA was supposed to improve the adaptability of plant microbe interaction [107].

\section{Conclusions}

The study provided insight into the diversity of endophytic fungal community isolated from $\mathrm{D}$. chinense growing in the TGR area. This was the first report where studies on the diversity of endophytic fungus that inhabited D. chinense plant growing in the TGR area had been carried out. The data obtained showed that of the 154 endophytic fungal extracts screened for antioxidant, antimicrobial and anticancer potential. Among the 154 isolates tested, most of the endophytic fungal extracts showed abundant bioactivity. Specifically, the I. lacteus DR10-1 extract exhibited significant antioxidant, antimicrobial and anticancer potential. By expanding fermentation I. lacteus DR10-1 strain, two active secondary metabolites, indole-3-carboxylic acid (1) and indole-3carboxaldehyde (2), were obtained, and they showed abundant biological activities. Therefore, we had for the first time reported its extract for bioactivity such as antioxidant, antimicrobial and anticancer potential. It was demonstrated that it could harbor metabolites that could serve as promising antioxidant, antimicrobial and anticancer agents.

\section{Supplementary information}

Supplementary information accompanies this paper at https://doi.org/10 1186/s12866-019-1634-0.

Additional file 1: Table S1. Endophytic fungi from $D$. chinense and corresponding isolation frequency (IF). Table S2. Antioxidant activity of endophytic fungi from $D$. chinense. Three experimental replicates were taken for the assay. Table S3. Antimicrobial activity of endophytic fungi from $D$. chinense. The indicator organisms included gram-negative: Escherichia coli (EC), Pseudomonas aeruginosa (PA); gram-positive: Staphylococcus aureus (SA), Bacillus subtilis (BS); three pathogenic fungi Penicillium (P), Aspergillus niger (AN) and Candida albicans (CA). All experiments were repeated three times. Table S4. Anticancer activity of endophytic fungi from $D$. chinense. The indicator cells included human papillary thyroid carcinoma cell line $\mathrm{IHH} 4$ and human pancreatic adenocarcinoma cell line CFPAC-1. The experiments repeated for three times.

Additional file 2: Figure S1. Morphological characteristics and microscopic morphology of DR10-1. Figure S2. Neighbor-joining tree based on ITS rDNA sequence of the fungus DR10-1 and its closest ITS rDNA matches in the GenBank. Figure S3. ${ }^{1} \mathrm{H}$ NMR spectrum of compound 1 in CD3COCD3. Figure S4. ${ }^{13} \mathrm{C}$ and DEPT NMR spectrum of compound $\mathbf{1}$ in CD3COCD3. Figure S5. ${ }^{1} \mathrm{H}$
NMR spectrum of compound $\mathbf{2}$ in CD3COCD3. Figure $\mathbf{S 6} .{ }^{13} \mathrm{C}$ and DEPT NMR spectrum of compound $\mathbf{2}$ in CD3COCD3.

\section{Abbreviations}

AN: Aspergillus niger; BS: Bacillus subtilis; CA: Candida albicans;

$\mathrm{CHCl}_{3}$ : Chloroform; D': Margalef Index; DNA: DeoxyriboNucleic Acid; DPPH: 2,2'-diphenyl-b-picrylhydrazyl; Ds: Simpson's Diversity Index; EC: Escherichia coli; EtOAc: Ethyl Acetate; H': Shannon-Wiener Index $\mathrm{HgCl}$ : Mercuric Chloride; IF: Isolation Frequency; ITS: Internal Transcribed Spacer; JC: Jaccard Similarity Index; MeOH: Methanol; N: Number of Isolates; NMR: Nuclear Magnetic Resonance; P: Penicillium; PA: Pseudomonas aeruginosa; PDA: Potato Dextrose Agar; PDB: Potato Dextrose Broth; ROS: Reactive Oxygen Species; S: Species Richness Index; SA: Staphylococcus aureus; SD: Standard Deviation; TGR: Three Gorges Reservoir; Vc: Ascorbic Acid; Zl: Inhibitory Zones

\section{Acknowledgements}

The authors are thankful to the Prof. Hongping Deng and were preserved in Chongqing Key Laboratory of Plant Resource Conservation and Germplasm Innovation, School of Life Science, Southwest University, Chongqing for his kind support.

\section{Authors' contributions}

XXD contributed to the experimental conception and design, the process of the whole project for carrying out the related experiments, data analysis, and manuscript draft; FFX contributed to the fungal isolate culture and data analysis; DQ, TCG, WYS, SHZ, BHY, JRX, YJP, contributed reagents, materials, and analysis tools; JYD contributed to the experimental design as well as the manuscript draft and improvement. All authors read and approved the final manuscript.

\section{Funding}

This work was financially supported by the Natural Science Foundation of Chongqing (grant numbers cstc2017jcyjAX0225, cstc2018jcyjA0864), the Medicinal and Healthy Technology Project of Zhejiang Province, China (grant numbers 2017KY642), and Science and Technology Project of Huzhou (grant numbers 2017GY32)

\section{Availability of data and materials}

Sequences obtained in this study were deposited in the NCBI GenBank database (For accession numbers refer Table $\mathrm{S} 1$ of the Additional file 1). Other datasets used and/or analyzed during the current study are available from the corresponding author upon reasonable request.

\section{Ethics approval and consent to participate}

No specific permission was required for the described study area. The research work doesn't involve any endangered or protected plant species.

\section{Consent for publication}

Not applicable.

\section{Competing interests}

The authors declare that they have no competing interests.

\section{Author details}

${ }^{1}$ Chongqing Key Laboratory of Plant Resource Conservation and Germplasm Innovation, School of Life Sciences, Southwest University, Chongqing 400715, People's Republic of China. ${ }^{2}$ Laboratory Animal Research Institute of Chongqing Academy of Chinese Materia Medica, Chongqing 400065, People's Republic of China. ${ }^{3}$ First Affiliated Hospital, Huzhou Teachers College, The First People's Hospital of Huzhou, 158 Guangchanghou Road, Huzhou 313000, People's Republic of China.

Received: 7 September 2019 Accepted: 6 November 2019

Published online: 10 December 2019

References

1. Song HC, Qin D, Han MJ, Wang L, Zhang K, Dong JY. Bioactive 2-pyrone metabolites from an endophytic Phomopsis asparagi SWUKJ5.2020 of Kadsura angustifolia. Phytochem Lett. 2017;22:235-40. 
2. Rodriguez R, Redman R. More than 400 million years of evolution and some plants still can't make it on their own: plant stress tolerance via fungal symbiosis. J Exp Bot. 2008;59:1109-14.

3. Lata R, Chowdhury S, Gond SK, White JJF. Induction of abiotic stress tolerance in plants by endophytic microbes. Lett Appl Microbiol. 2018;66:268-76.

4. Gonzalez-Menendez V, Crespo G, de Pedro N, Diaz C, Martin J, Serrano R, Mackenzie TA, Justicia C, Gonzalez-Tejero MR, Casares M, Vicente F, Reyes F, Tormo JR, Genilloud O. Fungal endophytes from arid areas of Andalusia: high potential sources for antifungal and antitumoral agents. Sci Rep. 2018; 8 (1) : 9729-

5. Pan X, Qin Y, Yuan Z. Potential of a halophyte-associated endophytic fungus for sustaining Chinese white poplar growth under salinity. Symbiosis. 2018; 76:109-16.

6. Amin N. Endophytic fungi to control of cocoa pod borer (Conopomorpha cramerella) on cocoa plantation. Research Journal of Pharmaceutical Biological \& Chemical Sciences. 2016;7:1496-501.

7. Hartley SE, Eschen R, Horwood JM, Gange AC, Hill EM. Infection by a foliar endophyte elicits novel arabidopside-based plant defence reactions in its host. Cirsium arvense. New Phytol. 2015;205:816-27.

8. Potshangbam M, Devi SI, Sahoo D. Strobel GA. Functional Characterization of Endophytic Fungal Community Associated with Oryza sativa L. and Zea mays L. Front Microbiol. 2017;8:325

9. Radhakrishnan R, Khan AL, Lee IJ. Endophytic fungal pre-treatments of seeds alleviates salinity stress effects in soybean plants. J Microbiol. 2013;51:850-7.

10. Estrada C, Wcislo WT, Van Bael SA. Symbiotic fungi alter plant chemistry that discourages leaf-cutting ants. New Phytol. 2013;198:241-51.

11. Hamed I, Özogul F, Özogul Y, Regenstein JM. Marine Bioactive Compounds and Their Health Benefits: A Review. Compr Rev Food Sci. 2015;14:446-65.

12. Debbab A, Aly AH, Proksch P. Bioactive secondary metabolites from endophytes and associated marine derived fungi. Fungal Divers. 2011;49:1-12.

13. Julia K, Abdessamad D, Aly AH, Peter P. Methods for isolation of marinederived endophytic fungi and their bioactive secondary products. Nat Protoc. 2010;5:479-90.

14. Silva-Hughes AF, Wedge DE, Cantrell CL, Carvalho CR, Pan Z, Moraes RM, Madoxx VL, Rosa LH. Diversity and antifungal activity of the endophytic fungi associated with the native medicinal cactus Opuntia humifusa ( Cactaceae ) from the United States. Microbiol Res. 2015;175:67-77.

15. Deshmukh SK, Verekar SA, Bhave SV. Endophytic fungi: a reservoir of antibacterials. Front Microbiol. 2014;5:715.

16. Chen L, Zhang QY, Jia M, Ming QL, Yue W, Rahman K, Qin LP, Han T. Endophytic fungi with antitumor activities: Their occurrence and anticancer compounds. Crit Rev Microbiol. 2014:1-20.

17. Zhang D, He H, Liu M, Meng Z, Guo S. A novel assay for screening inhibitors targeting HIV-1 integrase dimerization based on Ni-NTA magnetic agarose beads. Sci Rep. 2016;6:25375.

18. Cui JL, Guo TT, Ren ZX, Zhang NS, Wang ML. Diversity and antioxidant activity of culturable endophytic fungi from alpine plants of Rhodiola crenulata, R. angusta, and R. sachalinensis. PLoS One. 2015;10:e0118204

19. Venkateswarulu N, Shameer S, Bramhachari PV, Basha SKT, Nagaraju C, Vijaya T. Isolation and characterization of plumbagin (5- hydroxyl- 2methylnaptalene-1,4-dione) producing endophytic fungi Cladosporium delicatulum from endemic medicinal plants: Isolation and characterization of plumbagin producing endophytic fungi from endemic medicinal plants. Biotechnol Rep (Amst). 2018; 20: e00282.

20. Li X, Li N, Yang J, Ye F, Chen F, Chen F. Morphological and photosynthetic responses of riparian plant Distylium chinense seedlings to simulated Autumn and Winter flooding in Three Gorges Reservoir Region of the Yangtze River. China. Acta Ecologica Sinica. 2011;31:31-9.

21. Liu Z, Cheng R, Xiao W, Guo Q, Wang Y, Wang N, Wang Y. Leaf gas exchange, chlorophyll fluorescence, non-structural carbohydrate content and growth responses of Distylium chinense during complete submergence and subaerial re-emergence. Aquatic Botany. 2015;124:70-7.

22. Yang F, Wang Y, Chan Z. Perspectives on screening winter-flood-tolerant woody species in the riparian protection forests of the three gorges reservoir. Plos One. 2014;9:e108725.

23. Lu LF, Jiang MX, Huang HD, Bao DC. Can the soil seed bank contribute to revegetation of the drawdown zone in the Three Gorges Reservoir Region. Plant Ecology. 2010;209:153-65.

24. Yong W, Liu YF, Liu SB, Huang HW. Molecular phylogeny of Myricaria (Tamaricaceae): implications for taxonomy and conservation in China. Bot Stud. 2009;50:343-52.
25. Perez IB, Brown PJ. The role of ROS signaling in cross-tolerance: from model to crop. Front Plant Sci. 2014:5:754.

26. Xie CH. SRAP Analysis of Genetic Diversity of Riparian Plant Distylium chinense in Hubei Province. . 2012; 32: 311-319.

27. Chen FQ, Xie ZQ. Survival and growth responses of Myricaria laxiflora seedlings to summer flooding. Aquat Bot. 2009;90:333-8.

28. Terzi H, Yildiz M. Interactive effects of sulfur and chromium on antioxidative defense systems and BnMP1 gene expression in canola (Brassica napus L.) cultivars differing in $\mathrm{Cr}(\mathrm{VI})$ tolerance. Ecotoxicology. 2015;24:1171-82.

29. Yu Y, Yuan S, Zhuang J, Wan Y, Wang Q, Zhang J, Li H. Effect of selenium on the uptake kinetics and accumulation of and oxidative stress induced by cadmium in Brassica chinensis. Ecotoxicol Environ Saf. 2018;162:571-80.

30. Jr WJ, Torres MS. Is plant endophyte-mediated defensive mutualism the result of oxidative stress protection? Physiol Plantarum. 2010;138:440-6.

31. Khan AL, Lee IJ. Endophytic Penicillium funiculosum LHLO6 secretes gibberellin that reprograms Glycine max L. growth during copper stress. BMC Plant Biology. 2013;13:86.

32. Khan AL, Waqas M, Khan AR, Hussain J, Kang SM, Gilani SA, Hamayun M, Shin JH, Kamran M, Al-Harrasi A. Fungal endophyte Penicillium janthinellum LK5 improves growth of ABA-deficient tomato under salinity. World J Microb Biot. 2013:29:2133-44.

33. Zhou J, Diao X, Wang T, Chen G, Lin Q, Yang X, Xu J. Phylogenetic diversity and antioxidant activities of culturable fungal endophytes associated with the mangrove species Rhizophora stylosa and R. mucronata in the South China Sea. Plos One. 2018; 13: e0197359.

34. Yan XT, Lee SH, Li W, Sun YN, Yang SY, Jang HD, Kim YH. Evaluation of the antioxidant and anti-osteoporosis activities of chemical constituents of the fruits of Prunus mume. Food Chem. 2014:156:408-15.

35. Hecht F, Pessoa CF, Gentile LB, Rosenthal D, Carvalho DP, Fortunato RS. The role of oxidative stress on breast cancer development and therapy. Tumour Biol. 2016;37:4281-91.

36. Chi CF, Wang B, Wang YM, Zhang B, Deng SG. Isolation and characterization of three antioxidant peptides from protein hydrolysate of bluefin leatherjacket (Navodon septentrionalis) heads. J Funct Foods. 2015;12:1-10.

37. Wang B, Gong YD, Li ZR, Yu D, Chi CF, Ma JY. Isolation and characterisation of five novel antioxidant peptides from ethanol-soluble proteins hydrolysate of spotless smoothhound (Mustelus griseus) muscle. J Funct Foods. 2014;6:176-85.

38. Torre LA, Bray F, Siegel RL, Ferlay J, Lortet-Tieulent J, Jemal A. Global cancer statistics, 2012. CA Cancer J Clin. 2015;65:87-108.

39. Vargiu AV, Pos KM, Poole K, Nikaido H. Editorial: Bad Bugs in the XXIst Century: Resistance Mediated by Multi-Drug Efflux Pumps in Gram-Negative Bacteria. Front Microbiol. 2016;7:833.

40. Lei S, Zeng B, Xu S, Zhang X. Response of basal metabolic rate to complete submergence of riparian species Salix variegata in the Three Gorges reservoir region. Sci Rep. 2017:7:13885.

41. Yang L, Deng HP, Han M, Lei SY. Seed Characteristics of Distylium chinense (Fr.) Diels in the Three-Gorges Reservoir Region. Journal of Southwest University. 2008; 30: 79-84.

42. Xie CH, Li XL, Luan CY, Yang J, Chen FJ, Li ZY. SRAP Analysis of Genetic Diversity of Riparian Plant Distylium chinense in Hubei Province. Bulletin of Botanical Research. 2012:32:311-9.

43. Han GY, Hou KL, He HH. Preliminary study on cuttings of Distylium chinense (Fr.) Diels. J Chongqing For Sci Tech. 2005;71:22-3.

44. Li X, Wang X, Luan C, Yang J, Cheng S, Dai Z, Mei P, Huang C. Somatic embryogenesis from mature zygotic embryos of Distylium chinense (Fr.) Diels and assessment of genetic fidelity of regenerated plants by SRAP markers. Plant Growth Regul. 2014; 74: 11-21.

45. Liu Z, Cheng R, Xiao W, Guo Q, Wang N. Effect of off-season flooding on growth, photosynthesis, carbohydrate partitioning, and nutrient uptake in Distylium chinense. PLoS One. 2014;9:e107636.

46. Liu YC. Study on Distylium of the Three Gorges area in Chongqing and Wujiang River area. Environment \& Ecology in the Three Gorges. 2008.

47. Huang $\mathrm{Q}$, An HM, Song HC, Mao HQ, Shen WY, Dong JY. Diversity and biotransformative potential of endophytic fungi associated with the medicinal plant Kadsura angustifolia. Res Microbiol. 2015;166(1):45-55.

48. Strobel G, Yang X, Sears J, Kramer R, Sidhu RS, Hess WM. Taxol from Pestalotiopsis microspora, an endophytic fungus of Taxus wallachiana. Microbiology. 1996;142:435-40.

49. Landum MC, Felix Mdo R, Alho J, Garcia R, Cabrita MJ, Rei F, Varanda CM. Antagonistic activity of fungi of Olea europaea $\mathrm{L}$. against Colletotrichum acutatum. Microbiol Res. 2016;183:100-8. 
50. White TJ, Bruns T, Lee S, Taylor J. Amplification and direct sequencing of fungal ribosomal RNA genes for phylogenetics. Pcr Protocols. 1994; 38:315-22.

51. Tamura K, Dudley J, Nei M, Kumar S. MEGA4: Molecular Evolutionary Genetics Analysis (MEGA) software version 4.0. Mol Biol Evol. 2007; 24: 1596-1599.

52. Edgar R. MUSCLE: multiple sequence alignment with high accuracy and high throughput. Nucleic Acids Res. 2004;32:1792-7.

53. Koichiro T, Masatoshi N, Sudhir K. Prospects for inferring very large phylogenies by using the neighbor-joining method. Proc Natl Acad Sci USA. 2004;101:11030-5.

54. Kaur J, Bhambri P, Gupta OP. Distance based Phylogenetic Trees with Bootstrapping. International Journal of Computer Applications. 2013;47:6-10.

55. LV YL, Zhang FS, Chen J, Cui JL, Xing YM, Li XD, Guo SX. Diversity and antimicrobial activity of endophytic fungi associated with the alpine plant Saussurea involucrata. Biol Pharm Bull. 2010;33:1300.

56. Zhao J, Fu Y, Luo M, Zu Y, Wang W, Zhao C, Gu C. Endophytic fungi from pigeon pea [Cajanus cajan (L.) Millsp.] produce antioxidant Cajaninstilbene acid. J Agric Food Chem. 2012;60:4314-9.

57. Rios JL, Recio MC, Villar A. Screening methods for natural products with antimicrobial activity: A review of the literature. J Ethnopharmacol. 1988;23: $127-49$.

58. Sun W, Lan X, Wang Z, Dong W, He L, Zhang T, Zhang P, Zhang H. MicroRNA-144 inhibits proliferation by targeting WW domain-containing transcription regulator protein 1 in papillary thyroid cancer. Oncology Lett. 2018; 15: 1007-1013.

59. Zhang Q, Zhang J, Yang L, Zhang L, Jiang D, Chen W, Li G. Diversity and biocontrol potential of endophytic fungi in Brassica napus. Biol Control. 2014;72:98-108.

60. Santos JM, Correia VG, Phillips AJL. Primers for mating-type diagnosis in Diaporthe and Phomopsis : their use in teleomorph induction in vitro and biological species definition. Fungal Biol. 2010;114:255-70.

61. Schoch CL, Shoemaker RA, Seifert KA, Hambleton S, Spatafora JW, Crous PW. A multigene phylogeny of the Dothideomycetes using four nuclear loci. Mycologia. 2017;98:1041-52.

62. Venkatachalam A, Thirunavukkarasu N, Suryanarayanan TS. Distribution and diversity of endophytes in seagrasses. Fungal Ecol. 2015;13:60-5.

63. Li PQ, Wu Z, Liu T, Wang YN. Biodiversity, Phylogeny, and Antifungal Functions of Endophytic Fungi Associated with Zanthoxylum bungeanum. Int J Mol Sci. 2016; 17(9): 1541-

64. Jiang S, Wang W, Xue X, Cao C, Zhang Y. Fungal diversity in major oil-shale mines in China. J Environ Sci. 2016:41:81-9.

65. Xiao HT, Liu B, Hao XY, Yang XS, Sun QY. Chemical constituents from Saussurea deltoidea. Chem Nat Compd. 2009;45:539.

66. Maria-Teresa GL, Woldemichael GM, Singh MP, Suarez PA, Maiese WM, Gloria M, Timmermann BN. Isolation of three new naturally occurring compounds from the culture of Micromonospora sp. P1068. Nat Prod Res. 2005;19:645-52.

67. Tian W, Bi YH, Zeng W, Jiang W, Xue YH, Wang GX, Liu SP. Diversity of endophytic fungi of Myricaria laxiflora grown under pre- flooding and postflooding conditions. Genet Mol Res. 2015;14:10849-62.

68. Li HY, Zhao CA, Liu CJ, Xu XF. Endophytic fungi diversity of aquatic/riparian plants and their antifungal activity in vitro. J Microbiol. 2010;48:1-6.

69. Bråthen KA, Jahiri X, Soininen EM, Jensen JB. Fungal endophyte diversity in tundra grasses increases by grazing. Fungal Ecol. 2015;17:41-51.

70. Suryanarayanan TS, Thirunavukkarasu N, Rajulu MBG, Venkatesan G, Sukumar R. Endophytic fungal communities in woody perennials of three tropical forest types of the Western Ghats, southern India. Biodveirs Conserv. 2011; 20:913-28.

71. U'Ren JM, Lutzoni F, Miadlikowska J, Laetsch AD, Arnold AE. Host and geographic structure of endophytic and endolichenic fungi at a continental scale. Am J Bot. 2012;99:898.

72. Sandberg DC, Battista $\amalg$, Arnold AE. Fungal Endophytes of Aquatic Macrophytes: Diverse Host-Generalists Characterized by Tissue Preferences and Geographic Structure. Microb Ecol. 2014;67:735-47.

73. Smith SE, Read DJ. Mycorrhizal Symbiosis. (Academic Press, 2008).

74. Vergara C, Urquiaga KE, Schultz CS, Balieiro N, Medeiros FC, Santos PS, Xavier AGR, Zilli JE. Dark Septate Endophytic Fungi Help Tomato to Acquire Nutrients from Ground Plant Material. Front Microbiol. 2017:8:2437.

75. An HM, Liu Y, Zhao XF, Huang Q, Yuan SH, Yang XY, Dong JY. Characterization of cadmium-resistant endophytic fungi from Salix variegata Franch. in Three Gorges Reservoir Region, China. Microbiol Res. 2015;176:29-37.
76. Weishampel PA, Bedford BL. Wetland dicots and monocots differ in colonization by arbuscular mycorrhizal fungi and dark septate endophytes. Mycorrhiza. 2006;16:495-502.

77. Stevens KJ, Wellner MR, Acevedo MF. Dark septate endophyte and arbuscular mycorrhizal status of vegetation colonizing a bottomland hardwood forest after a 100 year flood. Aquat Bot. 2010;92:105-11.

78. Rukachaisirikul V, Arunpanichlert J, Sukpondma Y, Phongpaichit S, Sakayaroj J. Metabolites from the endophytic fungi Botryosphaeria rhodina PSU-M35 and PSU-M114. Tetrahedron. 2009:65:10590-5.

79. Massonnet M, Figueroa-Balderas R, Galarneau ERA, Miki S, Lawrence DP, Sun Q, Wallis CM, Baumgartner K, Cantu D. Neofusicoccum parvum Colonization of the Grapevine Woody Stem Triggers Asynchronous Host Responses at the Site of Infection and in the Leaves. Front Plant Sci. 2017:8:1117.

80. Armengol J, Moretti A, Perrone G, Vicent A, Bengoechea JA, García-Jiménez J. Identification, incidence and characterization of Fusarium proliferatum on ornamental palms in Spain. Eur J Plant Pathol. 2005;112:123-31.

81. Rodriguez R, Redman R. More than $\mathbf{4 0 0}$ million years of evolution and some plants still can't make it on their own: plant stress tolerance via fungal symbiosis. J Exp Bot. 2008;59:1109-14.

82. Kogel KH, Franken P, Hückelhoven R. Endophyte or parasite-what decides? Curr Opin Plant Biol. 2006:9:358-63.

83. Hendry SJ, Boddy L, Lonsdale D. Abiotic variables effect differential expression of latent infections in beech (Fagus sylvatica). New Phytol. 2002; 155:449-60.

84. Moricca S, Ragazzi A. Fungal endophytes in Mediterranean oak forests: a lesson from Discula quercina. Phytopathology. 2008;98:380-6.

85. Halmschlager E. Endophytic fungi in leaves and twigs of Quercus petrea. Eur J For Pathol. 1993;23:51-63.

86. Akello J, Dubois T, Gold CS, Coyne D, Nakavuma J, Paparu P. Beauveria bassiana (Balsamo) vuillemin as an endophyte in tissue culture banana (Musa spp.). J Invertebr Pathol. 2007;96:34-42.

87. Bae H, Sicher RC, Kim MS, Kim SH, Strem MD, Melnick RL, Bailey BA. The beneficial endophyte Trichoderma hamatum isolate DIS 219b promotes growth and delays the onset of the drought response in Theobroma cacao. J Exp Bot. 2009;60:3279-95.

88. Zeng W, Qin W, Tian W, Xue Y, Liu S. Antioxidant activity in vitro of endophytic fungi from Myricaria laxiflora, a riparian plant with strong tolerance ability of flooding. J Pure Appl Microbio. 2015:9:87-95.

89. Hamilton CE, Helander M, Saikkonen K. Endophytic mediation of reactive oxygen species and antioxidant activity in plants: a review. Fungal Divers. 2012;54:1-10

90. Mirzahosseini Z, Shabani L, Sabzalian MR, Sharifi-Tehrani M. Neotyphodium endophytes may increase tolerance to Ni in tall fescue. Eur J Soil Biol. 2014; 63:33-40.

91. Mirzahossini Z, Shabani L, Sabzalian MR, Sharifi-Tehrani M. ABC transporter and metallothionein expression affected by $\mathrm{NI}$ and Epichloe endophyte infection in tall fescue. Ecotox Environ Safe. 2015;120:13-9.

92. Katoch M, Singh G, Sharma S, Gupta N, Sangwan PL, Saxena AK. Cytotoxic and antimicrobial activities of endophytic fungi isolated from Bacopa monnieri (L.) Pennell (Scrophulariaceae). BMC Complem Altern M. 2014; 14: 52-52

93. Phongpaichit S, Rungjindamai N, Rukachaisirikul V, Sakayaroj J. Antimicrobial activity in cultures of endophytic fungi isolated from Garcinia species. FEMS Immunol Med Microbiol. 2006;48:367-72.

94. Guimaraes DO, Borges WS, Kawano CY, Ribeiro PH, Goldman GH, Nomizo A, Thiemann OH, Oliva G, Lopes NP, Pupo MT. Biological activities from extracts of endophytic fungi isolated from Viguiera arenaria and Tithonia diversifolia. FEMS Immunol Med Microbiol. 2008;52:134-44.

95. Jung WJ, Jo GH, Kuk JH, Kim KY, Park RD. Extraction of chitin from red crab shell waste by cofermentation with Lactobacillus paracasei subsp. tolerans KCTC-3074 and Serratia marcescens FS-3. Appl Microbiol Biotechnol. 2006; 71:234-7.

96. Gebreyohannes G, Moges F, Sahile S, Raja N. Isolation and characterization of potential antibiotic producing actinomycetes from water and sediments of Lake Tana, Ethiopia. Asian Pacific Journal of Tropical Biomedicine. 2013;3:426-35.

97. Nath A, Raghunatha P, Joshi SR. Diversity and Biological Activities of Endophytic Fungi of Emblica officinalis, an Ethnomedicinal Plant of India. Mycobiology. 2012:40:8-13.

98. Singh DK, Sharma VK, Kumar J, Mishra A, Verma SK, Sieber TN, Kharwa RN. Diversity of endophytic mycobiota of tropical tree Tectona grandis Linn.f: Spatiotemporal and tissue type effects. Sci Rep. 2017; 7: 3745. 
99. Abreu LM, Costa SS, Pfenning LH, Takahashi JA, Larsen TO, Andersen B. Chemical and molecular characterization of Phomopsis and Cytospora-like endophytes from different host plants in Brazil. Fungal Biol-UK. 2012;116: 249-60.

100. Massonnet M, Morales-Cruz A, Figueroa-Balderas R, Lawrence DP, Baumgartner K, Cantu D. Condition-dependent co-regulation of genomic clusters of virulence factors in the grapevine trunk pathogen Neofusicoccum parvum. Mol Plant Pathol. 2018;19:21-34.

101. Alberti I, Prodi A, Nipoti P, Grassi G. First report of Neofusicoccum parvum causing stem and branch canker on Cannabis sativa in Italy. J Plant Dis Protect. 2018;125:511-3.

102. Song F, Wu SH, Zhai YZ, Xuan QC, Wang T. Secondary metabolites from the genus Xylaria and their bioactivities. Chem Biodivers. 2014;11:673-94.

103. Dzoyem JP, Melong R, Tsamo AT, Maffo T, Kapche DGWF, Ngadjui BT, McGaw LJ, Eloff JN. Cytotoxicity, antioxidant and antibacterial activity of four compounds produced by an endophytic fungus Epicoccum nigrum associated with Entada abyssinica. Rev Bras Farmacogn. 2017;27:251-3.

104. Himaja M, Jose T, Ramana MV, Anand R, Munirajasekhar D. SYNTHESIS AND BIOLOGICAL EVALUATION OF INDOLE-3-CARBOXYLIC ACID DERIVATIVES OF AMINO ACIDS AND PEPTIDES. International Research Journal of Pharmacy. 2010;1:436-40.

105. Meena KK, Sorty AM, Bitla UM, Choudhary K, Gupta P, Pareek A, Singh DP, Prabha R, Sahu PK, Gupta VK, Singh HB, Krishanani KK, Minhas PS. Abiotic Stress Responses and Microbe-Mediated Mitigation in Plants: The Omics Strategies. Front Plant Sci. 2017;8:172.

106. Hartley SE, Gange AC. Impacts of plant symbiotic fungi on insect herbivores: mutualism in a multitrophic context. Annu Rev Entomol. 2009;54:323-42.

107. Chowdhury MEK, Jeon J, Rim SO, Park YH, Lee SK, Bae H. Composition, diversity and bioactivity of culturable bacterial endophytes in mountaincultivated ginseng in Korea. Sci Rep. 2017;7:10098.

\section{Publisher's Note}

Springer Nature remains neutral with regard to jurisdictional claims in published maps and institutional affiliations.

Ready to submit your research? Choose BMC and benefit from:

- fast, convenient online submission

- thorough peer review by experienced researchers in your field

- rapid publication on acceptance

- support for research data, including large and complex data types

- gold Open Access which fosters wider collaboration and increased citations

- maximum visibility for your research: over $100 \mathrm{M}$ website views per year

At $\mathrm{BMC}$, research is always in progress.

Learn more biomedcentral.com/submissions 